\title{
DAMPAK PENERAPAN PMK RI NOMOR 122/PMK.010/2015 TERHADAP WAJIB PAJAK PEMOTONG PPH PASAL 21/26 DI WILAYAH KERJA KPP PRATAMA SEKAYU
}

\author{
Oleh : \\ Irlan Fery SE,M.Si \\ irlanfery81@yahoo.co.id \\ Budi Ismantoro
}

\begin{abstract}
Abstraksi
Pajak merupakan sektor unggulan yang menjadi primadona bagi pendapatan negara dari tahun ke tahun yang terus meningkat. Pada tahun 2015 DJP menargetkan pendapatan dari sektor Pajak sebesar Rp. 1.294 Triliun atau 76,68\% dari total Penerimaan APBN. Adanya perubahan Tarif PTKP paling tidak akan berdampak juga pada penerimaan pendapatan negara. Tujuan penelitian ini adalah untuk mengetahui bagaimana dampak dan mekanisme setelah penerapan PMK RI Nomor 122/PMK.010/2015 terhadap wajib pajak pemotong PPh Pasal 21/26 di wilayah kerja KPP Pratama Sekayu.dari data yang di dapatkan pada penelitian yang dilakukan penulis diketahui bahwa terdapat 5.147 wajib pajak pemotong PPh Pasal 21/26 yang terdaftar dan hanya 1.082 wajib pajak yang menyampaikan SPT PPh pasal 21/26 dan telah terjadi penurunan PPh pasal 21/26 pada tahun 2015.
\end{abstract}

Kata Kunci : PPh Pasal 21/26, SPT, PTKP.

\section{PENDAHULUAN}

Direktorat Jenderal Pajak (DJP) merupakan institusi yang diberikan wewenang penuh dalam menghimpun penerimaan pajak di Indonesia. Hal ini terlihat dari penerimaan Negara yang berasal dari pajak mendominasi sekitar 76,68\% dari total penerimaan dalam APBN Tahun 2015 Yakni sebesar Rp. 1.294 Triliun atau naik 20,69\% dari Tahun 2014.Selain porsi yang dominan, dari target penerimaan yang diemban oleh DJP senantiasa meningkat dari tahun ke tahun.Peningkatan target penerimaan pajak sebagaimana dapat dilihat dalam tabel 1.

Tabel 1

Target Penerimaan Pajak Nasional

Tahun 2012 s.d. 2015

(dalam triliun rupiah)

\begin{tabular}{|c|c|c|}
\hline Tahun & Target & Kenaikan \\
\hline 2012 & 884,99 & $15,88 \%$ \\
\hline 2013 & 995,21 & $12,45 \%$ \\
\hline 2014 & $1.072,38$ & $7,75 \%$ \\
\hline 2015 & $1.294,26$ & $20,69 \%$ \\
\hline
\end{tabular}

Sumber: www.pajak.go.id (diakses tanggal 13 April2016, data diolah) 
Meskipun demikian, DJP akan terus bekerja keras agar target penerimaan pajak bisa tercapai setiap tahunnya dengan optimalisasi beberapa sektor yang memang telah menjadi sasaran sejak lama. Salah satu penerimaan yang dominan dari sektor pajak penghasilan adalah PPh Pasal 21/26 atas penghasilan yang dipotong oleh wajib pajak pemotong PPh Pasal 21/26 terhadap gaji pegawai/karyawannya. Menurut Peraturan Direktur Jenderal Pajak Nomor PER32/PJ/2015, Pajak Penghasilan Pasal 21/26 (PPh Pasal 21/26) adalah pajak atas penghasilan berupa gaji, upah, honorarium, tunjangan, dan pembayaran lain dengan nama dan dalam bentuk apapun sehubungan dengan pekerjaan atau jabatan, jasa, dan kegiatan yang dilakukan oleh orang pribadi subyek pajak dalam negeri.

Penghasilan Tidak Kena Pajak, disingkat PTKP diatur dalam UndangUndang Nomor 36 Tahun 2008 tentang Perubahan Keempat atas Undang-Undang Nomor 7 Tahun 1983 tentang Pajak Penghasilanmerupakan unsur pengurang dalam penghitungan pajak penghasilan orang pribadi. Berdasarkan Peraturan Menteri Keuangan Republik Indonesia Nomor 122 Tahun 2015 tentang Penyesuaian Besarnya Penghasilan Tidak Kena Pajak yang menetapkan bahwa terhitung mulai Januari 2015 pemerintah telah menaikkan batasan PTKP.sebagaimana dapat dilihat pada tabel 2.

Tabel 2

Perubahan Penyesuaian Besarnya Penghasilan Tidak Kena Pajak (PTKP) Per Tahun

\begin{tabular}{|l|l|l|}
\hline $\begin{array}{c}\text { PMK No. } \\
\text { 122/PMK.010/2015 }\end{array}$ & $\begin{array}{c}\text { PMK No. } \\
\text { 162/PMK.011/2012 }\end{array}$ & \multicolumn{1}{|c|}{ Keterangan } \\
\hline Rp. 36.000.000,00 & Rp. 24.300.000,00 & $\begin{array}{l}\text { untuk diri wajib pajak orang } \\
\text { pribadi dan istri yang } \\
\text { penghasilannya digabung dengan } \\
\text { penghasilan suami }\end{array}$ \\
\hline Rp. 3.000.000,00 & Rp. 2.025.000,00 & $\begin{array}{l}\text { tambahan untuk wajib pajak yang } \\
\text { kawin }\end{array}$ \\
\hline Rp. 3.000.000,00 & Rp. 2.025.000,00 & $\begin{array}{l}\text { tambahan untuk setiap anggota } \\
\text { keluarga sedarah dan keluarga } \\
\text { semenda dalam garis keturunan } \\
\text { lurus serta anak angkat yang } \\
\text { menjadi tanggungan sepenuhnya, } \\
\text { paling banyak 3 orang untuk setiap } \\
\text { keluarga. }\end{array}$ \\
\hline
\end{tabular}

Sumber: Peraturan Menteri Keuangan No. 122/PMK.010/2015 dan Peraturan Menteri Keuangan No. 162/PMK.011/2012

Di samping itu, wajib pajak selaku Pemotong PPh Pasal 21/26diberlakukan mekanisme khusus dalam melakukan penyesuaian terhadap perhitungan, penyetoran dan pelaporan $\mathrm{PPh}$ Pasal 21/26 atas karyawan/pegawainya.Wajib pajak selaku pemotong PPh Pasal 21/26 diharuskan menghitung kembali PPh Pasal 21/26 terutang dan melakukan pembetulan SPT 
untuk masa pajak Januari s.d. Juni 2015. Dalam perhitungan tersebut terdapat perbedaan perhitungan yang menyebabkan perhitungan $\mathrm{PPh}$ terutang menjadi lebih kecil daripada yang seharusnya dipotong/disetor. Kelebihan atas pemotongan dan penyetoran $\mathrm{PPh}$ Pasal 21 tersebut akan dikompesasikan ke masa pajak berikutnya atau masa pajak Juli 2015 dan seterusnya. Atas kelebihan pemotongan tersebut Wajib Pajak diharuskan melakukan pembetulan SPT Masa PPh Pasal 21/26 masa pajak Januari s.d. Juni 2015 dan menyampaikan pembetulan SPT Masa PPh Pasal 21/26 ke KPP Pratama terkait.

Namun demikian, Peraturan Menteri Keuangan ini tidak serta merta diterapkan secara langsung oleh wajib pajak selaku pemotong $\mathrm{PPh}$ Pasal 21/26. Berdasarkan hasil survey pendahuluan kepada wajib pajak dikarenakan beberapa faktor, salah satunya seperti kurangnya sosialisasi yang dilaksanakan oleh Kantor Pelayanan Pajak (KPP)sebagai perpanjangan tangan dari Direktorat Jenderal Pajak. Adapun faktorlain yang menjadi kendala adalah kurangnya minat dari wajib pajak untuk lebih aktif dalam mengikuti perkembangan perubahan peraturan perpajakan yang dinamis sehingga masih banyak wajib pajak yang belum mengetahui perubahan peraturan perpajakan meskipun pihak KPP sendiri sering melakukan berbagai macam sosialisasi.

Dengan mengacu pada uraian diatas, peneliti memandang bahwapenyesuaian besarnya PTKP yang dilakukan pada pertengahan tahun dan diberlakukan secara mundur sejak awal tahun 2015 di tengah kondisi perekonomian dunia dan nasional yang saat ini sedang melambat dan sosialisasi yang dilakukan oleh KPPbelum maksimal serta kurangnya kemauan wajib pajak untuk mengikuti perkembangan peraturan perpajakan yang menyebabkan masih banyak wajib pajak belum menerapkan Peraturan Menteri Keuangan ini.Oleh karena itu, penelitian ini, peneliti melakukan penelitian dengan pendekatan kualitatif untuk mengeksplorasi pemahaman dari Dampak Penerapan PMK RI Nomor 122/PMK.010/2015 terhadap Wajib Pajak Pemotong PPh Pasal 21/26 di Wilayah Kerja KPP Pratama Sekayu.

\section{KONSEP PAJAK PENGHASILAN}

Defenisi Penghasilan menurut Pasl 4 ayat (1) UU no. 36 Tahun 2008 Tetntang Pajak Pengasilan, menyatakan bahwa penghasilan adalah setiap tambahan kemampuan ekonomis yang diterima atau diperoleh oleh wajib pajak, baik yang berasal dari Indonesia maupun dari luar Indonesia, yang dapat dipakai untuk dikonsumsi atau untuk menambah kekayaan wajib pajak yang bersangkutan, dengan nama dan dalam bentuk apapun.

\section{PENGHASILAN TIDAK KENA PAJAK (PTKP)}

Pajak penghasilan merupakan pajak subjektif sehingga dalam pengenaannya harus memperhatikan keadaan pribadi subjek pajak.Hal ini diwujudkan dengan pemberian kelonggaran berupa Penghasilan Tidak Kena Pajak (PTKP).PTKP merupakan standar kehidupan minimum yang diberikan negara kepada wajib pajak.PTKP ini telah mengalami beberapa kali perubahan. Tarif PTKP terbaru untuk perhitungan $\mathrm{PPh}$ Pasal 21/26 berdasarkan PMK RI Nomor 122/PMK010/2015 sebagaimana tersaji pada tabel 2 sebelumnya. 
Berdasarkan Peraturan Direktorat Jenderal Pajak Nomor PER32/PJ/2015bagi pegawai tidak tetap atau tenaga kerja lepas yang penghasilannya tidak dibayar secara bulanan atau jumlah kumulatifnya dalam 1 (satu) bulan kalender belum melebihi $\mathrm{Rp} 3.000 .000,00$ (tiga juta rupiah), maka berlaku ketentuan berikut ini:

- Tidak dilakukan pemotongan PPh Pasal 21/26, jika penghasilan sehari belum melebihi Rp 300.000,-;

- Dilakukan pemotongan PPh Pasal 21/26, jika penghasilan sehari sebesar atau melebihi $\mathrm{Rp} 300.000$,- tersebut merupakan jumlah yang dapat dikurangkan dari penghasilan bruto;

- Bila pegawai tidak tetap memperoleh penghasilan kumulatif dalam 1 (satu) bulan kalender melebihi $\mathrm{Rp} 3.000 .000$,- maka jumlah tersebut dapat dikurangkan dari penghasilan bruto;

- Rata-rata penghasilan sehari adalah rata-rata upah mingguan, upah satuan, atau upah borongan untuk setiap hari kerja yang digunakan.

- PTKP sebenarnya adalah sebesar PTKP untuk jumlah hari kerja yang sebenarnya.

- $\quad$ PTKP sehari sebagai dasar untuk menetapkan PTKP yang sebenarnya adalah sebesar PTKP per tahun Rp 36.000.000,- dibagi 360 hari.

- Bila pegawai tidak tetap atau tenaga kerja lepas tersebut mengikuti program jaminan atau tunjangan hari tua, maka iuran yang dibayar sendiri dapat dikurangkan dari penghasilan bruto.

\section{TARIF PAJAK PENGHASILAN}

Menurut Resmi (2011:4), tarif pajak dapat berupa angka atau persentase tertentu. Jenis tarif pajak dibedakan menjadi empat, yaitu:

a. Tarif tetap

Tarif tetap adalah tarif berupa jumlah atau angka yang tetap, berapapun besarnya dasar pengenaan pajak.

b. Tarif proposional (sebanding)

Tarif proposional adalah tarif yang berupa persentase tertentu yang sifatnya tetap terhadap berapapun dasar pengenaan pajaknya.

c. Tarif progresif (meningkat)

Tarif progresif adalah tarif berupa persentase tertentu yang semakin meningkat dengan semakin meningkatnya dasar pengenaan pajak.

d. Tarif degresif (menurun)

Tarif degresif adalah tarif berupa persentase tertentu yang semakin menurun dengan semakin meningkatnya dasar pengenaan pajak.

Tarif pajak penghasilan yang digunakan di Indonesia adalah tarif pajak penghasilan yang diatur dalam pasal 17 UU RI No. 36 Tahun 2008 sebagaimana dapat dilihat pada tabel 3 sebagai berikut : 
Tabel 3

Tarif PPh Terutang

\begin{tabular}{|l|l|}
\hline \multicolumn{1}{|c|}{ Lapisan Penghasilan Kena Pajak } & \multicolumn{1}{c|}{ Tarif Pajak } \\
\hline Sampai dengan Rp 50.000.000,- (lima puluh juta rupiah) & $5 \%$ (lima persen) \\
\hline $\begin{array}{l}\text { Di atas Rp 50.000.000,- (lima puluh juta rupiah) sampai } \\
\text { dengan Rp 250.000.000,00 (dua ratus lima puluh juta rupiah) }\end{array}$ & $\begin{array}{l}\text { 15\% (lima belas } \\
\text { persen) }\end{array}$ \\
\hline $\begin{array}{l}\text { Di atas Rp 250.000.000,- (dua ratus lima puluh juta rupiah) } \\
\text { sampai dengan Rp 500.000.000,- (lima ratus juta rupiah) }\end{array}$ & $\begin{array}{l}\text { 25\% (dua puluh lima } \\
\text { persen) }\end{array}$ \\
\hline Di atas Rp 500.000.000,- (lima ratus juta rupiah) & $\begin{array}{l}30 \% \text { (tiga puluh } \\
\text { persen) }\end{array}$ \\
\hline $\begin{array}{l}\text { Untuk wajib pajak yang tidak memiliki NPWP, dikenakan tarif 20\% lebih tinggi dari } \\
\text { yang memiliki NPWP. }\end{array}$
\end{tabular}

Sumber: Undang-Undang RI No 36 Tahun 2008 tentang Pajak Penghasilan

\section{KONSEP PPH PASAL 21/26 DAN SURAT PEMBERITAHUAN (SPT)PPH PASAL 21/26}

Berdasarkan Peraturan Direktur Jenderal Pajak Nomor PER-32/PJ/2015, Pajak Penghasilan Pasal 21/26 (PPh Pasal 21/26) adalah pajak atas penghasilan berupa gaji, upah, honorarium, tunjangan, dan pembayaran lain dengan nama dan dalam bentuk apapun sehubungan dengan pekerjaan atau jabatan, jasa, dan kegiatan yang dilakukan oleh orang pribadi subyek pajak dalam negeri.

Subjek pajak penghasilan pasal $21 / 26$ adalah penerima penghasilan yang dipotong PPh pasal 21/26, terdiri atas pegawai yang memperoleh penghasilan dari pemberi kerja secara berkala, penerima pensiun, penerima honorarium, penerima upah, dan orang pribadi yang memperoleh penghasilan sehubungan dengan pekerjaan, jasa, atau kegiatan dari pemotong pajak. Pajak penghasilan pasal 21/26 merupakan pajak yang bersifat withholding system, yaitu pajak yang dipotong oleh orang lain atau pihak ketiga. Perhitungan jumlah pajak penghasilan pasal 21/26 yang harus dibayar oleh wajib pajak dilakukan dengan cara mengalikan penghasilan kena pajak dengan tarif pajak berdasarkan pasal 17 UU pajak penghasilan. Besarnya jumlah penghasilan kena pajak dari wajib pajak dihitung berdasarkan penghasilan netonya dikurangi dengan penghasilan tidak kena pajak.

Pemotong Pajak Penghasilan Pasal 21/26 meliputi:

1. Pemberi kerja yang terdiri dari orang pribadi dan badan, baik merupakan pusat maupun cabang, perwakilan atau unit yang membayar gaji, upah, honorarium, tunjangan, dan pembayaran lain dengan nama dan dalam bentuk apapun, sebagai imbalan sehubungan dengan pekerjaan atau jasa yang dilakukan oleh pegawai atau bukan pegawai;

2. Bendahara atau pemegang kas pemerintah, termasuk bendahara atau pemegang kas pada Pemerintah Pusat termasuk institusi TNI/POLRI, Pemerintah Daerah, instansi atau lembaga pemerintah, lembaga-lembaga negara lainnya, dan Kedutaan Besar Republik Indonesia di luar negeri, yang membayarkan gaji, upah, honorarium, tunjangan, dan pembayaran lain dengan nama dan dalam bentuk apapun sehubungan dengan pekerjaan atau jabatan, jasa, dan kegiatan;

3. Dana pensiun, badan penyelenggara jaminan sosial tenaga kerja, dan badan- 
badan lain yang membayar uang pensiun dan tunjangan hari tua atau jaminan hari tua;

4. Orang pribadi yang melakukan kegiatan usaha atau pekerjaan bebas serta badan yang membayar:

a. Honorarium atau pembayaran lain sebagai imbalan sehubungan dengan jasa dan/atau kegiatan yang dilakukan oleh orang pribadi dengan status Subjek Pajak dalam negeri, termasuk jasa tenaga ahli yang melakukan pekerjaan bebas dan bertindak untuk dan atas namanya sendiri, bukan untuk dan atas nama persekutuannya,

b. Honorarium atau pembayaran lain sebagai imbalan sehubungan dengan kegiatan dan jasa yang dilakukan oleh orang pribadi dengan status subjek pajak luar negeri,

c. Honorarium atau imbalan lain kepada peserta pendidikan, pelatihan, dan magang,

5. Penyelenggara kegiatan, termasuk badan pemerintah, organisasi yang bersifat nasional dan internasional, perkumpulan, orang pribadi serta lembaga lainnya yang menyelenggarakan kegiatan, yang membayar honorarium, hadiah, atau penghargaan dalam bentuk apapun kepada Wajib pajak orang pribadi dalam negeri berkenaan dengan suatu kegiatan.

\section{METODE PENELITIAN}

Penelitian ini dilakukan pada kantor KPP Pratama Sekayu yang beralamat ddi Jalan Pahlawan No.6 RT. 12 RW.05 LK.III, Kelurahan Kayuara Kecamatan Sekayu Kabupaten Musi Banyuasin. Objek analisis pada penelitian ini adalah realitas organisasi sebagai pelayanan kepada masyarakat dalam aktifitas perpajakan, yang di dalamnya terjadi interaksi antar individu dan struktur. Fenomena yang dipilih pada penelitian ini adalah masyarakat sebagai Wajib Pajak yang diwajibkan untuk mellakukan interaksi perpajakan yang berhubungan langsung dengan pelayanan yang diberikan oleh KPP Pratama Sekayu Musi Banyuasin.

Pengumpulan data dilakukan melalui pengamatan berpartisipasi, studi pustaka dan penelitian lapangan seperti observasi, wawancara dan dokumentasi. Pengamatan berpartisipasi dilakukan dengan cara keterlibatan peneliti di dalam proses perhitungan pemotongan pajak PPh Pasal 21/26 di Wilayah Kerja KPP Pratama Sekayu selama rentang waktu dua bulan. Wawancara dilakukan secara tidak struktur dan informal dalam berbagai situasi. Dokumentasi digunakan unruk mengungkap realitas sosial yang terjadi dan terdapat pada suatu dokumen.

\section{TEKNIK ANALISIS DATA}

Teknik analisis yang digunakan pada penelitian ini mengacu pada Sugiyono (2012: 333), bahwa analisis data adalah proses mencari dan menyusun secara sistematis data yang diperoleh dari hasil wawancara, pencatatan lapangan, kategori menjabarkan kedalam unit-unit, melakukan sintesa, menyusun kedalam pola, memilih mana yang penting dan yang akan dipelajari, dan maupun kesimpulan sehingga mudah dipahami oleh diri sendiri maupun orang lain. 
dalam penelitian ini penulis menggunakan data kualitatifyang diwujudkan dengan cara menggambarkan kenyataan atau keadaan-keadaan atau suatu objek dalam bentuk uraian kalimat berdasarkan keterangan-keterangan dari pihak-pihak yang berhubungan dengan penelitian ini. Proses analisis data secara kualitatif dimulai dengan menelaah data yang diperoleh dari berbagai sumber atau informasi, baik melalui wawancara maupun dokumentasi. Setelahsemua data danketeranganbaik (fakta-fakta dan catatan-catatan) yang diperlukan melalui proses teknik pengumpulan data selanjutnya langkah yang dilakukan Penulis adalah mengolah, menganalisa dan merincikan data tersebut dengan berpedoman pada literature dan landasan teori-teori yang telah ada sebagai bahan pertimbangan terhadap masalah yang diambil untuk diteliti, dan dengan hasil analisa data tersebut kemudian akan ditarik kesimpulan.Untuk meminimalisir kesalahan yang mungkin terjadi berkaitan dengan pengambilan sampel dan teknik wawancara digunakan triangulasi (penggabungan). Teknik ini bertujuan untuk melakukan pengecekan ulang dengan cara mengkombinasikan berbagai jenis metode kualitatif sehingga data yang diperoleh akan lebih konsisten, tuntas dan pasti.

\section{DAMPAK PENERAPAN PMK RI NO.122/PMK.010/2015 TERHADAP PENERIMAAN PPh PASAL 21/26 DI KPP PRATAMA SEKAYU.}

Berdasarkan data penulis dapatkan dari KPP Pratama Sekayu Musi Banyuasin yaitu pada laporan perbandingan penerimaan PPh pasal 21 per bulan tahun 2014 dan tahun 2015. Apabila dibandingkan dengan tahun sebelumnya penurunan $\mathrm{PPh}$ pasal 21/26 di tahun 2015 mulai terlihat pada semester kedua yaitu pada bulan Juli 2015. Penurunan ini bertepatan dengan diundangkannya PMK Nomor 122/PMK.010/2015 pada tanggal 29 Juni 2015 dimana peraturan ini memberlakukan penyesuaian besarnya PTKP sejak awal dan hasil dari perhitungan kembali PPh pasal 21/26 terutang dan pembetulan SPT PPh Masa Pasal 21/26 dimana hasil dari perhitungan tersebut mengakibatkan PPh pasal 21/26 yang terutang akan menjadi lebih kecil atau bahkan menyebabkan penghasilan kena pajak dari wajib pajak orang pribadi menjadi dibawah PTKP atau dapat dikatakan tidak ada PPh pasal 21/26 yang terutang.

Tabel 5

Laporan Perbandingan Penerimaan Per Bulan PPh Pasal 21 Tahun 2014 dan 2015

\begin{tabular}{|c|l|r|r|r|}
\hline No. & \multicolumn{1}{|c|}{ Bulan } & $\mathbf{2 0 1 4}$ & $\mathbf{2 0 1 5}$ & \multicolumn{1}{c|}{ Growth } \\
\hline 1. & Januari & 18.266 .954 .915 & 20.801 .533 .555 & $12,18 \%$ \\
\hline 2. & Ferbruari & 10.746 .999 .872 & 12.327 .041 .101 & $12,82 \%$ \\
\hline 3. & Maret & 15.305 .806 .130 & 15.795 .964 .912 & $3,10 \%$ \\
\hline 4. & April & 16.044 .275 .227 & 20.022 .006 .633 & $19,87 \%$ \\
\hline 5. & Mei & 16.948 .780 .446 & 16.551 .780 .736 & $-2,40 \%$ \\
\hline 6. & Juni & 16.655 .807 .362 & 16.927 .630 .862 & $1,61 \%$ \\
\hline 7. & Juli & 22.403 .186 .129 & 21.884 .289 .395 & $-2,37 \%$ \\
\hline 8. & Agustus & 25.957 .622 .554 & 26.048 .792 .547 & $0,35 \%$ \\
\hline 9. & September & 12.848 .197 .810 & 10.224 .736 .240 & $-25,66 \%$ \\
\hline 10. & Oktober & 13.766 .818 .425 & 13.641 .660 .451 & $-0,92 \%$ \\
\hline
\end{tabular}




\begin{tabular}{|l|l|r|r|r|}
\hline 11. & November & 16.984 .487 .939 & 16.981 .007 .551 & $-0,02 \%$ \\
\hline 12. & Desember & 26.429 .469 .308 & 19.257 .268 .429 & $-37,24 \%$ \\
\hline
\end{tabular}

Sumber : KPP Pratama Sekayu periode 31 Desember 2015.

Berdasarkan tabel diatas, dapat dilihat penurunan PPH Pasal 21/26 terjadi pada semester kedua tahun 2015, hal ini diakibatkan setengah dari 50 Wajib Pajak besar penentu penerimaan mengalami penurunan setoran PPh Pasal 21/26. Wajib pajak besar ini memberikan kontribusi penerimaan selama tahun 2015 sebesar Rp. 157.652.043.903 atau sekitar 81,84 \% dari total penerimaan PPh Pasal 21/26

\section{HASIL PENELITIAN}

\section{PEMBERLAKUAN PERATURAN YANG BERLAKU SURUT}

PMK RI Nomor 122/PMK.010/2015 yang diundangkan pada tanggal 29 Juni2015 yang berlaku surat sejak Januari 2015 berdampak bagi wajib pajak selaku pemberi kerja atau pemotong PPh pasal 21/26 diharuskan untuk melakukan penyesuaian atau perhitungan kembali atas PPh pasal21/26 dan pembetulan SPT PPh masa pasal 21/26 yang telah dilakukan sejak masa pajak Januari 2015 sampai denganmasa pajakwajib pajak tersebut mulai menerapkan perhitungan berdasarkan PMK ini.

\section{PERATURAN YANG TIDAK LANGSUNG DITERAPKAN OLEH WAJIB PAJAK}

Berdasarkandata yang didapat dari KPP Pratama Sekayu diketahui bahwa terdapat 5.147 wajib pajak pemotong $\mathrm{PPh}$ pasal 21/26 yang terdaftar dan hanya 1.082 wajib pajak yang menyampaikan SPT PPh pasal 21/26. PMK RI Nomor 122/PMK.010/2015 yang diundangkan pada pertengahantahun ternyata tidak mendapatkan respon cepat dari wajib pajak untuk segera menerapkannya. Sebagaiman pada tabel 4 diketahui bahwa mulai terlihat adanya peningkatan jumlah SPT PPh pasal 21/26 dengan status lebih bbayar yang diterima oleh KPP Pratama Sekayu pada bulan September 2015 sejumlah 93 SPT dan peningkatan jumlah ini terus berlanjut pada bulan - bulan berikutnya yaitu bulan September 2015 sebanyak 104 SPT, Oktober 2015 sebanyak 80 SPT, November 2015 sebanyak 95 SPT, dan bulan Desembar 2015 mencatat angkat paling signifikan yaitu sejumlah 151 SPT. 


\section{Tabel 4}

KPP Pratama Sekayu

Laporan Rekapitulasi Penerimaan SPT PPh Pasal PPh pasal 21/26

Tahun Pajak 2015

(Berdasarkan Status SPT)

\begin{tabular}{|c|c|c|c|c|c|c|c|c|c|c|c|c|c|}
\hline $\begin{array}{c}\text { STATUS } \\
\text { SPT }\end{array}$ & 1 & 2 & 3 & 4 & 5 & 6 & 7 & 8 & 9 & 10 & 11 & 12 & Jumlah \\
\hline $\begin{array}{c}\text { Kurang } \\
\text { Bayar }\end{array}$ & 1 & 235 & 294 & 294 & 286 & 281 & 263 & 291 & 345 & 290 & 341 & 347 & 3,268 \\
\hline $\begin{array}{c}\text { Lebih } \\
\text { Bayar }\end{array}$ & 1 & 2 & 1 & 1 & & 1 & 93 & 104 & 80 & 95 & 151 & 529 \\
\hline Nihil & 10 & 486 & 571 & 677 & 630 & 663 & 623 & 656 & 652 & 673 & 573 & 631 & 6,845 \\
\hline Jumlah & 11 & 722 & 687 & 972 & 917 & 944 & 887 & 1,040, & 1.101 & 1,043 & 1,009 & 1,129 & 10,642 \\
\hline
\end{tabular}

Sumber: KPP Pratama Sekayu, tahun 2015 Periode 31 desember 2015

Banyaknya wajib pajak yang belum dan bahkan tidak mengetahui adanya peraturan baru ini disebabkan oleh beberapa faktor. Berdasarkan hasil pengamatan dan wawancara dengan beberapa wajib pajak didapat hasil sebagai berikut: (1) Sedikit sekali wajib pajakyang secara mandiri dan proaktif mencari informasi terkait peraturan perpajakan dari berbagai sumber diluar KPP Pratama. (2) Terdapat wajib pajak yang memang bersikap tidak peduli terhadap peraturan ini. Wajib pajak juga beranggapan bahwa hasil perhitungan yang mengakibatkan lebih bayar pun tidak begitu membawa perubahan yang signifikan terhadap setoran PPh pasal 21/26. (3) Peraturan yang berlaku surut ini terlalu merepotkan bagi wajib pajak yang mengharuskan mereka melakukan perhitungan kembali Pphpasal 21/26 dan pembetulan SPT PPh masa pasal 21/26 yang telah dilakukan sejak masa pajak Januari 2015 dan melaporkannya pada KPP Pratama terkait. (4) Pihak KPP Pratama Sekayutidak secara langsung melakukan sosialisai kepada wajib pajak. Kegiatan sosialisasi terkait peraturan ini baru dilakukan pada awal bulan Agustus 2015 dikarenakan kegiatan sosialisasi yang memerlukan perencanaan dan dana yang memadai. Meskipun sosialisasi belum dilakukan pihak KPP Pratama Sekayu telah memberikan informasi kepada wajib pajak melalui Account Representative. Namun tidak semua wajib pajak mendapatkan informasi yang merata dan tidak begitu jelas dikarenakan informasi yang diberikan hanya melalui telepon dan tatap muka singkat sehingga wajib pajak belum mengetahui secara mendalamteknis dari penerapan PMK ini.

\section{PENERAPAN PMK YANG MENYEBABKAN ADANNYASELISIH LEBIH BAYAR}

Dalam melakukan perhitungan kembali atas $\mathrm{PPh}$ pasal 21/26 dengan berdasarkan PMK RI Nomor 122/PMK.010/2015, wajib pajak selaku pemberi kerja atau pemotong $\mathrm{PPh}$ pasal 21/26 akan mendapatkan hasil lebih bayar atas perhitungan tersebut.

\section{SELISIH LEBIH BAYAR YANG BERDAMPAK PADA PENERIMAAN PPH PASAL 21/26}


Adanya selisih lebih bayar dari hasil perhitungan kembali PPh pasal 21/26 mengakibatkan penurunan penerimaan $\mathrm{PPh}$ pasal 21/26 dikarenakan atas kelebihan bayar pada masa pajak yang dilakukan pembetulan SPT masa PPh Pasal 21/26 yang dikompensasikan pada masa pajak yang terdapat $\mathrm{PPh}$ pasal 21/26 yang kurang bayar.

\section{Mekanisme yang Harus dilakukan setelah penerapan PMK RI No.122/PMK.010/2015}

Selain itu selaku pemberi kerja/pemotong PPh Pasal 21/26, Wajib pajak wajib mematuhi mekanisme terkait penerapan PMK RI Nomor 122/PMK.010/2015, yaitu:

1. Melakukan perhitungan kembali PPh Pasal 21/26 terutang. Wajib pajak selaku pemberi kerja/pemotong PPh Pasal 21/26, diharuskan melakukan perhitungan kembali PPh pasal 21/26 terutang dengan menggunakan PTKP sebagaimana pada tabel 4 . Berdasarkan tabel tersebut dapat dijelaskan bahwa terdapat perubahan besarnya PTKP untuk setiap wajib pajak orang pribadi dan istri yang penghasilannya digabung dengan penghasilan suami dinaikkan menjadi Rp. 36.000.000,00 dari yang sebelumnya sebesar Rp. 24.300.000,00. Kemudian tambahan untuk wajib pajak yang kawin dinaikkan menjadi sebesar Rp. 3.000.000,00 dari yang sebelumnya sebesar Rp. 2.025.000,00 begitu pula untuk tambahan setiap anggota keluarga sedarah dan keluarga semenda dalam garis keturunan lurus serta anak angkat yang terjadi tanggungan sepenuhnya, paling banyak 3 orang untuk setiap keluarga dinaikkan menjadi sebesar Rp. 3.000.000,00 dari yang sebelumnya sebesar Rp. 2.025.000,00.

Dari hasil penelitian yang penulis dapatkan dari Kantor KPP Pratama Sekayu Musi Banyuasin salah satu contoh perhitungan PPh pasal 21/26 dari salah satu wajib pajak adalah:

\begin{tabular}{|c|c|}
\hline Nama Pegawai & : Subagio \\
\hline NPWP & : 00.000.000-314.000 \\
\hline Status & $: \mathrm{K} / 2$ \\
\hline Nama Pemberi Kerja & $\begin{array}{l}\text { : CONOCOPHILLIPS INDONESIA } \\
\text { INC.LTD }\end{array}$ \\
\hline Penghasilan Neto/Bulan & : Rp. 6.000.000,00 \\
\hline \multicolumn{2}{|l|}{ Perhitungan Awal } \\
\hline Penghasilan Neto disetahunkan & $=72.000 .000,00$ \\
\hline PTKP $(K / 2)$ & $=\underline{30.375 .000,00}$. \\
\hline Penghasilan Kena Pajak & $=\overline{41.625 .000,00}$ \\
\hline $\mathrm{PPh}$ Terutang Tarif Pasal 17(5\%) & $=2.081 .250,00$ \\
\hline PPh 1 Bulan & $=173.438,00$ \\
\hline \multicolumn{2}{|c|}{ Perhitungan Berdasarkan PMK Nomor 122/PMK.10/2015 } \\
\hline Penghasilan Neto Disetahunkan & $=72.000 .000,00$ \\
\hline PTKP (K/2) & $=\underline{45.000 .000,00}{ }_{-}$ \\
\hline
\end{tabular}


Penghasilan Kena Pajak

$\mathrm{PPh}$ Terutang Tarif pasal 17 (5\%)

PPh 1 Bulan

$$
\begin{aligned}
& =27.000 .000,00 \\
& =1.350 .000,00 \\
& =112.500,00
\end{aligned}
$$

Selisih Lebih Sektor $=173.438,00-112.500,00=60.938$

Dari perhitungan tersebut diketahui bahwa terdapat selisih sebesar 60.938 .

Lebih bayar inilah yang akan dikompensasikan atau dialihkan kepada masa pajakyang terdapat posisi $\mathrm{PPh}$ pasal 21/26 tersebut habis.

2. Melakukan pembetulan SPT PPh Pasal 21/26, Berdasarkan peraturan perundang-undangan pajak penghasilan diatur bahwa atas perhitungan kembali PPh pasal 21/26 oleh wajib pajak yang mengakibatkan kelebihan bayar tidak dapat direstitusi atau pengambilan pajak akan tetapi hanya dapat dikompensasikan atau dialihkan pada masa pajak yang terdapat posisi $\mathrm{PPh}$ pasal 21/26 kurang bayar. Proses kompensasi dituangkan dalam pembetulan SPT Masa PPh pasal 21/26 yang akan terus dilakukan sampai kelebihan bayar atas PPh pasal 21/26 tersebut habis. Sebagai contoh dan mengacu dari hasil penelitian pada objek penelitian yang penulis dapatkan yaitu pada perhitungan kembali PPh pasal 21/26 pada masa pajak januari 2015 terdapat kelebihan bayar sebesar Rp. 3.000.000 lalu pada masa September 2015 terdapat PPh pasal 21/26 yang kurang dibayar sebesar Rp. 10.000.000, maka kelebihan bayar sebesar Rp. 3.000.000 akan mengurangi PPh pasal 21/26 pada masa September 2015, sehingga $P P h$ pasal $21 / 26$ pada masa september 2015 menjadi Rp. 7.000 .000 (Rp. 10.000.000-3.000.000). Begitu pula jika pada masa pajak Februari 2015 terdapat kelebihan bayar sebesar Rp. 5.000.000, kelebihan inipun akan dikompensasikan pada masa september 2015, sehingga PPh pasal 21/26 terutang pada masa September 2015 menjadi sebesar Rp. 2.000.000 (Rp. 10.000.000-Rp. 3.000.000-Rp. 5.000.000). Pembetulan ini akan terus dilakukan sampai posisi $\mathrm{PPh}$ pasal 21/26 yang kurang dibayar habis dan apabila masih terdapat kelebihan pembayaran hal serupa akan dilakukan untuk masa Oktober 2015 dan seterusnya.

3. Melakukan pembetulan SPT masa PPh pasal 21/26 ke KPP terkait.Yaitu setelah wajib pajak Menghitung kembali PPh pasal 21/26 terutang dan melakukan pembetulan SPT Masa PPh pasal 21/26, langka berikutnya yang harus dilakukan oleh wajib pajak adalah menyampaikan atau melaporkan pembetulan SPT Masa PPh pasal 21/26 ke KPP Pratama terkait dalam hal ini KPP Pratama Sekayu.

\section{DAFTAR PUSTAKA}

Dewan Perwakilan Rakyat RI, 2008, Undang-Undang Nomor 36 Tahun 2008, Tentang Perubahan Keempat atas Undang-Undang Nomor 7 Tahun 1983 Tentang Pajak Penghasilan.

Direktorat Jenderal Pajak, 2015, PER-32/PJ/2015 
Kementerian Keuangan Republik Indonesia, 2012, PMK RI Nomor 162/PMK.011/2012,

Kementerian Keuangan Republik Indonesia, 2015, PMK RI Nomor 122/PMK.010/2015,

KPP Pratama Sekayu, 2015, Data Laporan Penerimaan SPTMasa PPh pasal 21/26 ( berdasarkan status Lebih Bayar) Tahun 2014 dan Tahun 2015

KPP Pratama Sekayu, 2015, Laporan Penerimaan PPh Pasal 21/26 Tahun 2015

KPP Pratama Sekayu, 2015, Laporan Perbandingan Penerimaan per Bulan PPh Pasal 21/26 Tahun 2015

Resmi, Siti, 2011. Perpajakan, Jakarta : Salemba Empat

Sugiyono,2012, Metode Penelitian Bisnis. ( Pendekatan Kuantitatif, Kualitatif dan $R \& D)$ Cetakan Ke Enam Belas Bandung : Alfabeta 